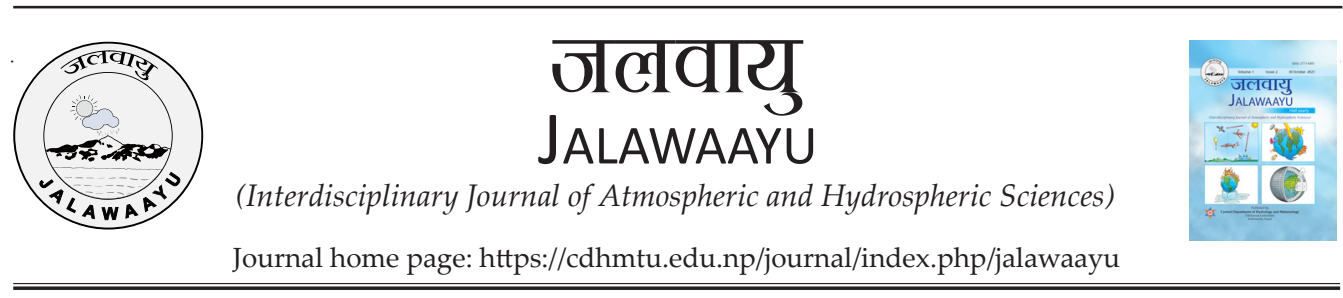

Research Article

\title{
Prediction of Thunderstorms based on Atmospheric Instability Indices over Bangladesh using WRF- ARW Model
}

Jannatul Ferdaus ${ }^{1 *}$, Dewan Abdul Quadir ${ }^{1}$, Md. Shadekul Alam², Subrat Kumar Panda $^{3}$, Someshwar Das ${ }^{3}$, Md. Nazmul Ahasan ${ }^{1}$, Khan Md. Golam Rabbani ${ }^{1}$ and Saurav Dey Shuvo ${ }^{1}$

1 Department of Meteorology, University of Dhaka, Dhaka, Bangladesh

2 Bangladesh Meteorological Department, Dhaka, Bangladesh

3 Department of Atmospheric Sciences, Central University of Rajasthan, India.

\begin{tabular}{l}
\hline ARTICLE INFO \\
\hline Received: 20 March 2021 \\
Received in Revised form: 31 May 2021 \\
Accepted: 3 June 2021 \\
Available Online: 2 December 2021 \\
\hline Keywords \\
\hline Thunderstorm \\
Instability Indices \\
Forecasting \\
Predictability \\
MCAPE \\
\hline${ }^{*}$ Correspondence \\
\hline Jannatul Ferdaus \\
jannatul-2nd-2018710803@met.du.ac.bd
\end{tabular}

Abstract: In this study an attempt has been made to inspect the forecasting of thunderstorms based on two cases ( $1^{\text {st }}$ case: $17^{\text {th }}$ May, 2019 and $2^{\text {nd }}$ case: $31^{\text {st }}$ March, 2019) over Dhaka using WRF Model. The model is run for 72 hours with 03 nested domain of $09 \mathrm{~km}, 03 \mathrm{~km}$ and $01 \mathrm{~km}$ horizontal resolutions using $0.25^{\circ} \mathrm{X}$ $0.25^{\circ}$ six hourly global data assimilation system. For model simulation, Milbrandt-Yau DoubleMoment 7-class scheme (9) has been used as microphysics scheme in this study. The model performance is evaluated by calculating hourly instability indices (VTI, TTI, KI, CTI, MCAPE, MCIN, BRN, LI, SI, SWI) value and have been compared with the threshold value of indices. Different meteorological parameters such as MSLP, temperature, winds at upper $(300 \mathrm{hPa})$ and lower (925 hPa) level, relative humidity along with vertical cross section are also studied by the model and compared with the favorable conditions for forming of thunderstorms. Area 
rage rainfall (hourly) value has been also calculated and compared with indices value to comprehend the nature of thunderstorms. Observing the indices value it is seen that all indices value increase sharply 5-6 hours before of thunderstorm occurring and MCAPE is giving more reliable result. Moreover, this study shows that inner two domains ( 3 and $1 \mathrm{~km}$ resolution) are giving better results than outer one and which indices are more probable in forecasting of thunderstorm for our country as well as giving less Root Mean square Error. From the simulated and validated results it can be concluded that the model performance of instability indices can be used as forecasting of thunderstorms over Bangladesh.

\section{Introduction}

Bangladesh (latitudes $20^{\circ} 34^{\prime}-26^{\circ} 38^{\prime} \mathrm{N}$ and longitudes $88^{\circ} 01^{\prime}-92^{\circ} 41^{\prime} \mathrm{E}$ ) is a disaster prone country. Every year it faces a lot of storm. Thunderstorm (TS) is one of them which occurred in high degree during pre-monsoon season in our country (Ahasan et al. 2014). These storms are designated as Nor 'westers in this region and locally known as 'Kalbaishakhi'. Western Disturbances are also responsible for the movement of thunderstorms in north-western India which brings moisture from the Arabian Sea. At this time a strong westerly jet take places over the country at the upper troposphere and generates associated atmospheric instabilities. Thunderstorm is also known as lightning storm because when thunderstorm occurs there is also seen presence of lightning acoustic effect on earth's atmosphere. Collision between the updrafts and downdrafts creates cumulonimbus cloud and these clouds are responsible for the occurrence of thunderstorm and lightning. Thunderstorms can develop everywhere, but it is frequent in mid-latitude because of warm, moist air from topical latitudes mixes with cooler air from polar latitudes. TS is one of the most dangerous convective weather events (Rahman et al. 2019). Supercells thunderstorms are most severe, rotate same as cyclones.

Thunderstorm which causes great damage to the socio-economic conditions. Thunderstorms have great impact on agricultural production. As for exampleThunderstorm with lightning and thunderstorm with hailstorm which makes agricultural lands become unsuitable. Thunderstorms are also responsible for aviation hazards and cause great damage to lives as well as resources (Litta et al. 2012).When the atmospheric condition is unstable and there is a high degree of variability through distance and time, then it is called atmospheric instability. According to G. T. Trewartha, "A thunderstorm is an intense instability outbreak." A stability index is used to measure the potential instability of the atmosphere. Various prospects of TS activity like formation, structure, timing and it's devastations have been studied and published in journals by such authors as Rai Sircar (1953), Koteswaran and Srinivasan (1958), Sen and Gupta (1961), De and Sen (1961), Nandi and Mukherjee (1966), Mukherjee and Bhattacharya (1972) and Mukherjee et al., (1977). Vujović et al. (2015) conducted a study on evaluation of the stability indices for the thunderstorm forecasting in the region of Belgrade, Serbia. A case study of 30 April, 2009 based on instability indices and forecasting of thunderstorm has been conducted by Tajbakhsh et al. (2012) where one meteorological case study for two Iranian airports are presented. For Bangladesh, only a limited number of research works have been done by the Bangladesh Meteorological Department which were presented in the seminar on "SEVERE LOCAL STORMS" 
organized by the South Asian Association for Regional Co-operation (SAARC) countries (Chowdhury and De, 1995). Karmakar and Alam (2006) has shown the instability of the troposphere connected with nor'westers by the pre-monsoon season over Bangladesh where the study attempts to find different stability indices in relation to the occurrence of nor'westers in order to find out the critical values of different indices favorable for the formation of thunderstorms as well as severe thunderstorms in Bangladesh. To forecast thunderstorms it is needed to know the inference of the level of atmospheric instability (Gubenko and Rubinshtein, 2014). Presumption of atmospheric instability is associated with the instability indices of different tropospheric layers. These indices are used in forecasting of thunderstorms globally (Gubenko and Rubinshtein, 2014).

In this study an attempt has been made to investigate the predictability of thunderstorms based on instability indices and verifying of thunderstorms forecast as obtained from WRF model using observational data. Two cases have been selected from the records of the squall data of Bangladesh Meteorological Department (BMD) for this study. Case-1 (12:50 UTC; 17th May, 2019) and Case-2 (12:22 UTC; 31st March, 2019) are selected over Dhaka (MOSDAC image in figure 1).

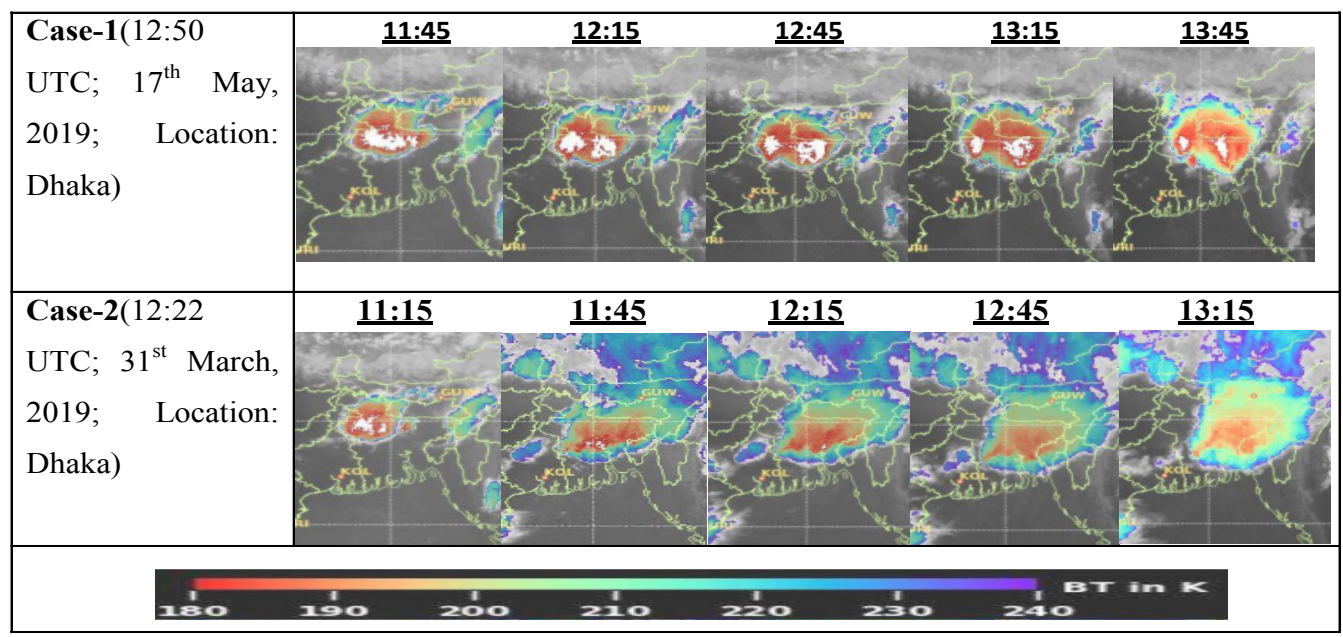

Figure 1. Cloud Image *(Source: MOSDAC, Based on the cloud coverage found from the Thermal Infrared Brightness Temperature image which is the outcome of Insat-3DR satellite of India).

\section{Materials and Methods}

This section provides a brief introduction about the WRF-ARW model, data used and the physical options incorporated to simulate and to analysis the selected events.

\subsection{Model Introduction}

The Weather Research and Forecasting (WRF) model is a numerical atmosphere or climate prediction (NWP) as well as simulation process planned for research including operational appeals too. There are two dynamics solvers in the WRF: The 
Advanced Research WRF (ARW) and the NMM (Non-hydrostatic Mesoscale Model). ARW is a configuration of the WRF system featuring the ARW dynamics solver together with other compatible components to produce a simulation. It is a subset of the WRF method that, including to the specific solver, surrounded by physics schemes, numeric/ dynamics options, initialization schedules, and a data assimilation bunch (WRFDA). ARW is supported as community model, facilitating system development and broad use for research, operations, and education. ARW's applications comprise realtime NWP, weather events as well as atmospheric-process lessons, data assimilation development, parameterized-physics development, regional climate simulation, air quality modeling, atmosphere-ocean coupling, and imagined atmosphere studies. The WRF-ARW (Version 4.0.3) has been implemented during the present study.

\subsection{Model Experimental Setup}

The WRF model is run on two-way nested domain at 9, 3 and $1 \mathrm{~km}$ horizontal resolution. The domain of WRF model for the NWP study with topography in the background is shown in figure 2 . Two cases are run in same domain.

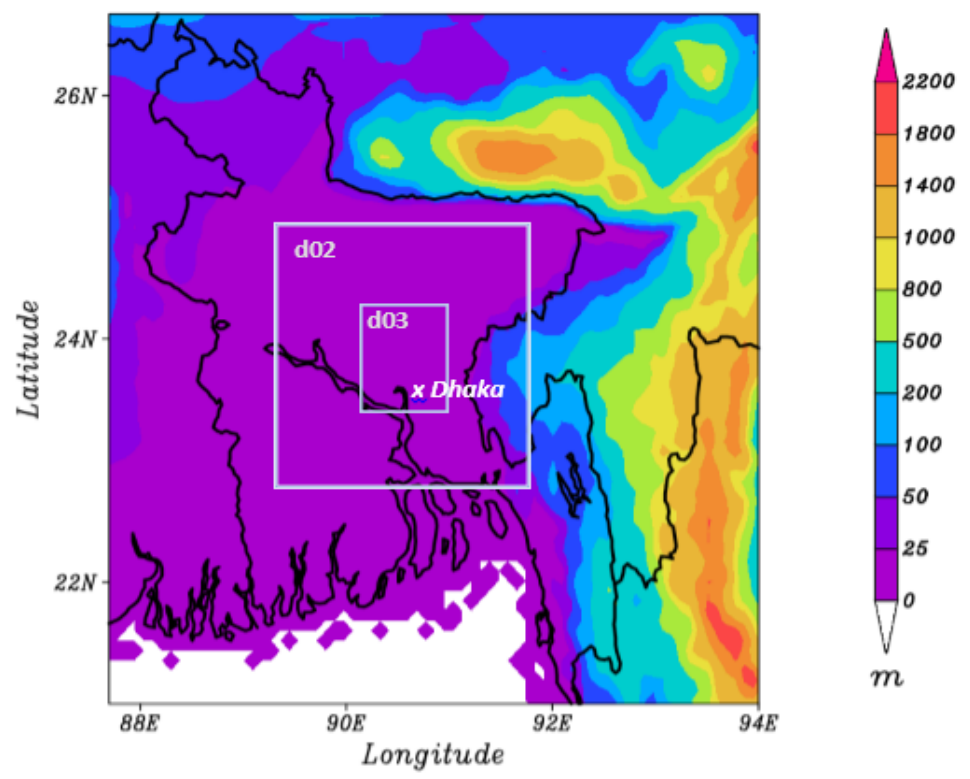

Figure 2. Model domain with topography in the background

For model simulation, Milbrandt as microphysics scheme, Krain-Fritsch (KF) as cumulus scheme, Yonsei University (YSU) as Planetary Boundary Layer (PBL) scheme, Rapid Radiative Transfer Model (RRTM) scheme for longwave, Dudhia scheme for shortwave radiation, Noah Land-Surface Model for surface physics and Revised MM5 for surface-clay physics have been used in this study (Table 1). 
Table 1. Brief description of model aspects and physical options

\begin{tabular}{|l|l|l|l|}
\hline $\begin{array}{l}\text { Model } \\
\text { Properties }\end{array}$ & Specification & Physics option & $\begin{array}{l}\text { Parameterization } \\
\text { schemes }\end{array}$ \\
\hline Version & WRF 4.0 .3 & Microphysics & $\begin{array}{l}\text { Milbrandt-Yau Double- } \\
\text { Moment 7-class scheme } \\
(9)\end{array}$ \\
\hline Spatial resolution & 9,3 and $1 \mathrm{~km}$ & $\begin{array}{l}\text { Cumulus } \\
\text { Parameterization }\end{array}$ & $\begin{array}{l}\text { Kain-Fritsch scheme (1), } \\
\text { for D-03 no cumulus (0) }\end{array}$ \\
\hline Vertical levels & 28 & PBL & $\begin{array}{l}\text { Yonsei University } \\
\text { scheme (1) }\end{array}$ \\
\hline Dynamics & Non-hydrostatic & $\begin{array}{l}\text { Longwave } \\
\text { Radiation }\end{array}$ & $\begin{array}{l}\text { Rapid Radiative } \\
\text { Transfer Model (1) }\end{array}$ \\
\hline Run period & 72 hours & $\begin{array}{l}\text { Shortwave } \\
\text { Radiation }\end{array}$ & Dudhia scheme (1) \\
\hline Map projection & Mercator & Sf_sfclay_physics & Revised MM5(1) \\
\hline $\begin{array}{l}\text { Initial and } \\
\text { lateral boundary } \\
\text { condition }\end{array}$ & $\begin{array}{l}0.25^{\circ} \text { X } 0.25^{\circ} \text { six } \\
\text { hourly global data } \\
\text { assimilation system } \\
\text { (GDAS) data }\end{array}$ & Sf_surface physics & $\begin{array}{l}\text { Noah Land-Surface } \\
\text { Model (1) }\end{array}$ \\
\hline
\end{tabular}

\subsection{Data Used}

The Global Data Assimilation System (GDAS) is the system used by the National Center for Environmental Prediction (NCEP). These NCEP FNL (Final) operational global analysis and prognosis data which are on 0.25 -degree by 0.25 -degree grids prepared operationally every six hours which are used here. Squall, rainfall and instability indices data from Bangladesh Meteorological Department and Wyoming University sounding data have been used in this study as observational data.

\subsection{Methodology}

The WRF-ARW Model developed by NCAR-NCEP, USA has been used for the study of the selected thunderstorms occurred over Dhaka. For every case the total time period of run was 72 hours on two-way nesting domain. From model output mean sea level pressure, Temperature, winds at different level, relative humidity along with vertical cross section have been also analyzed for both case. 10 instability indices have been calculated and has compared with threshold value of indices. They are- Vertical Totals Index (VTI), Total Totals Index (TTI), K Index, Cross Totals Index (CTI), Convective Available Potential Energy (CAPE), Convective Inhibition (CIN), Bulk Richardson Number (BRN), Lifted Index (LI), Showalter Index (SI), Severe Weather Index (SWI). Area average rainfall value is also calculated. After that hourly value of indices and rainfall (area average) of model has been shown graphically (by excel) for all domains to see the highest and lowest values of indices before storm and how it relates with rainfall. Root Mean Square Error (RMSE) has been calculated with the collected indices from Bangladesh Meteorological Department and Wyoming University at 00 UTC. 
Finally, rate of RMSE has been also calculated to demonstrate the performance of the model exercise.

\section{Results}

The WRF model simulated and derived parameters for the selected 2 thunderstorms cases (Case-1: 17 May 2019 and Case-2: 31 March 2019) have been presented and described below:

\subsection{Thermo Dynamical Features}

To understand the nature of the events date some thermos-dynamical features like MSLP, T, Winds at different levels, RH etc. have been analyzed here.

\subsubsection{Analysis of Sea Level Pressure}

The mean sea level pressure (MSLP) is the atmospheric pressure at mean sea level (PMSL). Average sea-level pressure is $1013.25 \mathrm{hPa}$. To form thunderstorms there is needed presence of an active elongated trough as well as a well-marked low over Gangetic plains of North-India including Bangladesh. For case-1 (12:50 UTC; $17^{\text {th }}$ May, 2019; Location: Dhaka) Model derived mean sea level pressure is $1003.32 \mathrm{hPa}$ which is valid for 1200 UTC over Dhaka and for case-2 (12:22 UTC; 31 ${ }^{\text {st }}$ March, 2019; Location: Dhaka), model derived MSLP is $1003.98 \mathrm{hPa}$ which valid for $1200 \mathrm{UTC}$ (Figure 3).

(a)

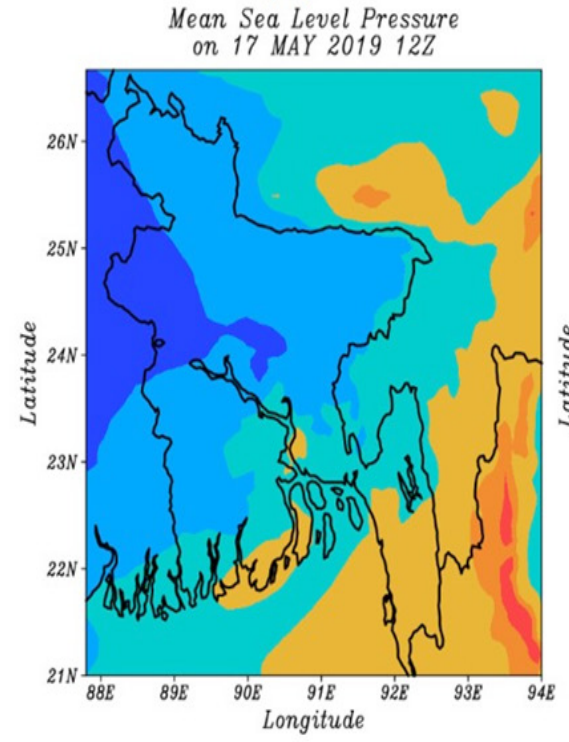

(b)

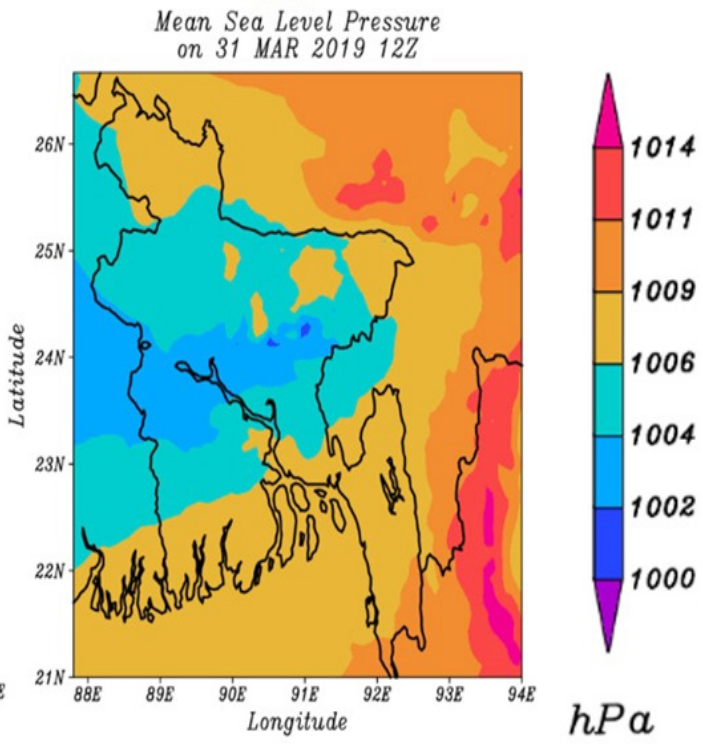

Figure 3. Spatial distribution of model simulated Mean Sea-Level Pressure (hPa) valid for 1200 UTC on 17 May 2019 (a) and 31 Mar 2019 (b). 


\subsubsection{Analysis of Temperature}

To form thunderstorm there is needed of warm temperature. The model derived dew point temperature $\left({ }^{\circ} \mathrm{C}\right)$ at $950 \mathrm{hPa}$ level of storm time for all selected cases are represented in figure 4 . For case-1 (12:50 UTC; $17^{\text {th }}$ May, 2019; Location: Dhaka) and case-2 (12:22 UTC; 31 ${ }^{\text {st }}$ March, 2019; Location: Dhaka) model derived T at $950 \mathrm{hPa}$ level is $26^{\circ} \mathrm{C}$ which is valid for $1200 \mathrm{UTC}$.

(a)

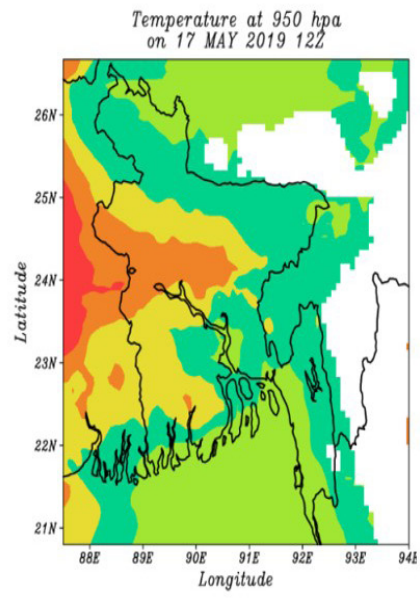

(b)

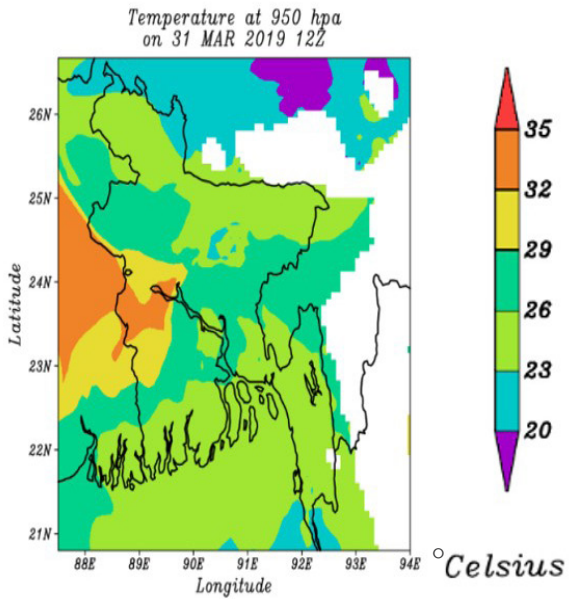

Figure 4. Spatial distribution of model simulated Dew point temperature $\left({ }^{\circ} \mathrm{C}\right)$ at 950 hPa level valid for 1200 UTC on 17 May 2019 (a) and 31 Mar 2019 (b).

\subsubsection{Analysis of low level wind $(925 \mathrm{hPa})$}

Wind is an important parameter in meteorology and winds carry moisture which acts as fuel in forming thunderstorm. The distribution of low level $(925 \mathrm{hPa})$ wind flow (knots) for all selected cases are given in figure 5. The strong southerlies weaken downstream as they travel northward, which may cause low level convergence, particularly near the hill slopes. The LLJ (Low Level Jet) is embedded in the southerly wind flow over the Bay of Bengal, which gets established east of the thermal low and the line of wind discontinuity that forms over the Indian Peninsula during this season due to continental heating (SMRC News Letter, Vol-11, No-2, 2004). For case-1 (12:50 UTC; $17^{\text {th }}$ May, 2019; Location: Dhaka), model derived low level wind (925 hPa) is northwesterly over Dhaka. And for case-2 (12:22 UTC; 31 ${ }^{\text {st }}$ March, 2019; Location: Dhaka), model derived low level wind $(925 \mathrm{hPa})$ is northernly over Dhaka with high speed of winds. There is seen the position of the dry line (a line where cold-dry air and wormmoist air meet together) which indicates the position of the Nor 'westers occurrence. 
(a)

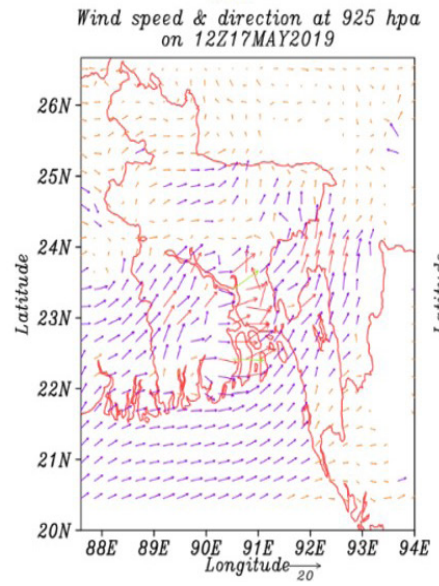

(b)

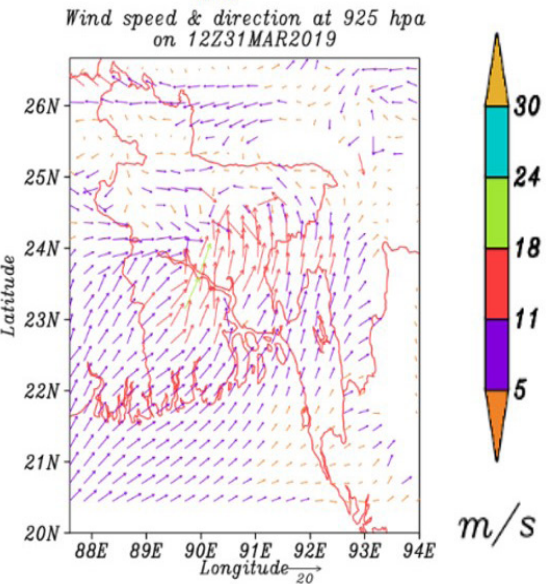

Figure 5. Spatial distribution of model simulated Low-level wind at $950 \mathrm{hPa}$ level valid for 1200 UTC on 17 May 2019 (a) and 31 Mar 2019 (b).

\subsubsection{Analysis of upper level winds ( $300 \mathrm{hPa})$}

At the time of occurrence of thunderstorm there is seen scatter wind normally. In this study, the distribution of upper level (300 hPa) wind flows (knots) for all selected casess are represented in figure 6 . For case 1 and case 2 there are seen that winds at 300 hpa level are not uniform over event location.

(a)

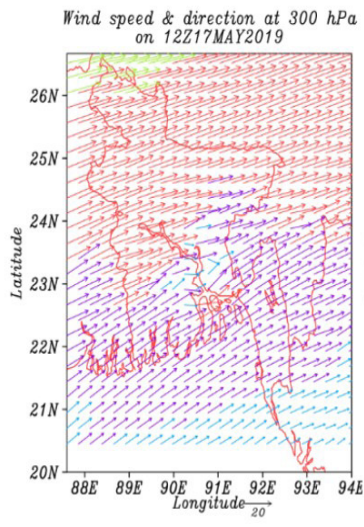

(b)

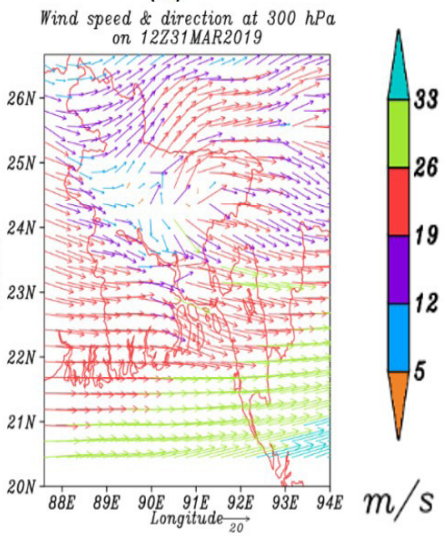

Figure 6. Spatial distribution of model simulated Upper-level wind at $300 \mathrm{hPa}$ level valid for 1200 UTC on 17 May 2019 (a) and 31 Mar 2019 (b). 


\subsubsection{Analysis of Relative Humidity}

Relative Humidity $(\mathrm{RH})$ is the ratio of the partial pressure of water vapor to the equilibrium vapor pressure of water at a given temperature. Relative Humidity (RH) depends on temperature and the pressure of the system of interest. Relative Humidity (RH) over $80 \%$ is one of conditions of thunderstorm formation (Meteoblue, University of Basel, Switzerland. 2019).

\section{Case-1 (12:50 UTC; 17 ${ }^{\text {th }}$ May, 2019; Location: Dhaka)}

In case of first event, the distribution of model simulated relative humidity (\%) valid at 1200 UTC of $17^{\text {th }}$ May 2019 (over Dhaka) is 70\% (Figure 7). The vertical crosssection of relative humidity displays that the $\mathrm{RH}$ condition in different heights of the cumulonimbus clouds indicates the presence of thunderstorm. The North-South (NS) vertical cross section of relative humidity, Longitude is fixed at 90.417 and for East-West (EW) vertical cross-section, Latitude is fixed at 23.78. The updraft and downdraft are clearly seen in the vertical profile of moisture. The envil shape of the thunderstorm at the mature stage is also clearly seen in the moisture profile. It is found that the intensity of vertical profile of the relative humidity field reaches up to $200 \mathrm{hPa}$.

(a)

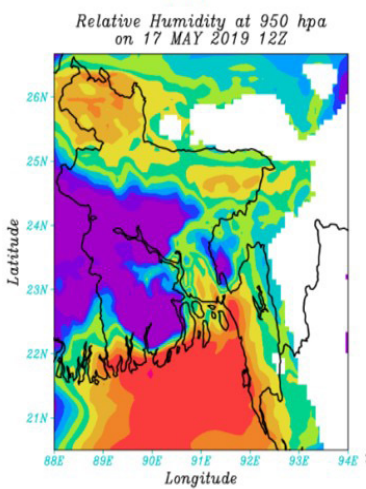

(b)

North-South Vertical Cross Section of Relative Humidity

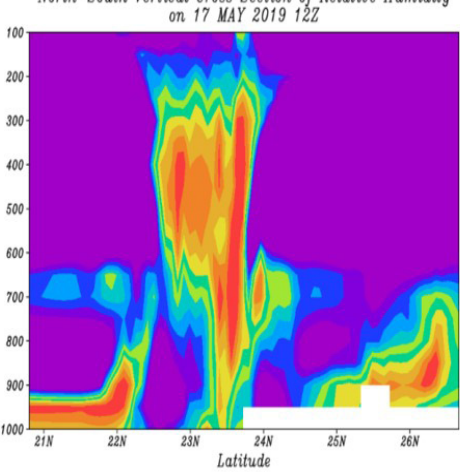

(c)

East-West Vertical Cross Section of Relative Humidity

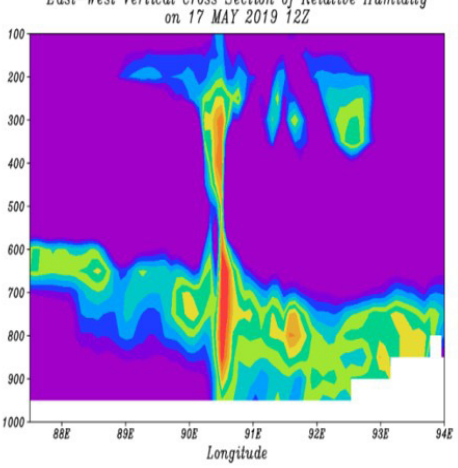

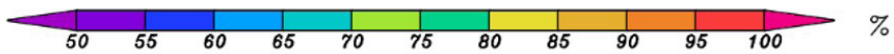

Figure 7. Spatial distribution of model simulated (a) relative humidity (\%); vertical profile of relative humidity (\%) (b) NS and (c) EW valid at 1200 UTC of $17^{\text {th }}$ May, 2019

\section{Case-2 (12:22 UTC; $31^{\text {st }}$ March, 2019; Location: Dhaka)}

For second case, the distribution of model simulated relative humidity (\%) valid at 1200 UTC of $31^{\text {st }}$ March 2019 is 50\% (Figure 8). For NS (North-South) vertical crosssection, Longitude of is fixed at 90.417 and for EW (East-West) vertical cross-section, Latitude is fixed at 23.78. It is found that the intensity of vertical profile of the relative humidity field reaches up to $200 \mathrm{hPa}$. 
(a)

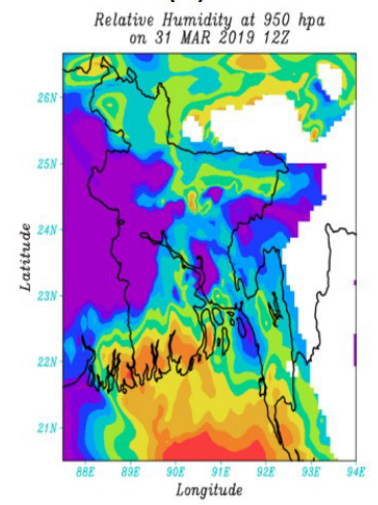

(b)

North-South Vertical Cross Section of Relative Humidity

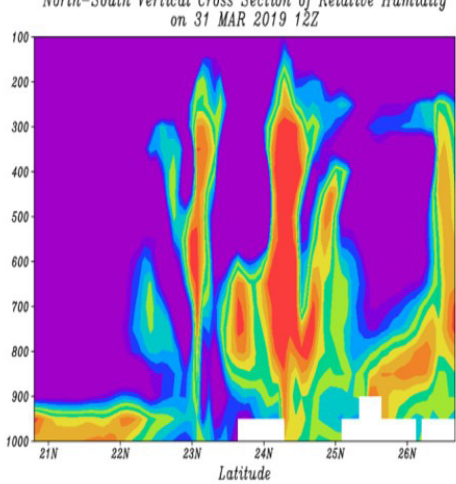

(c)

East-West Vertical Cross Section of Relative Humidity

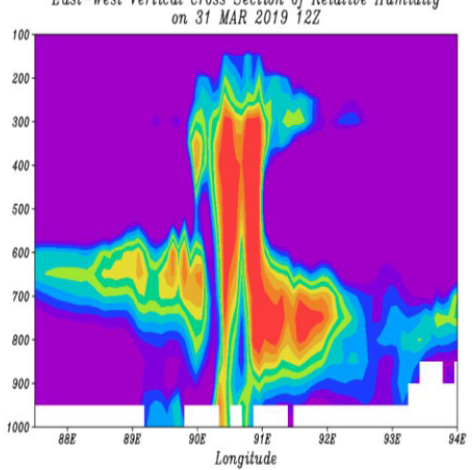

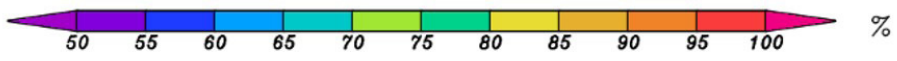

Figure 8. Spatial distribution of model simulated (a) relative humidity (\%); vertical profile of relative humidity (\%) (b) NS and (c) EW valid at 1200 UTC of 31 $1^{\text {st }}$ March, 2019.

\subsection{Instability Indices}

Different stability indices of the atmosphere are responsible for the occurrence of nor 'westers (TS) in our country as well as everywhere in the world. For our study, we have selected two severe cases over Dhaka. The different stability indices viz.VTI, TTI, CTI, KI, BRN, LI, SI, SWI have been calculated for each selected case. MCAPE and MCIN also have been calculated. But D-2 (horizontal resolution $3 \mathrm{~km}$ ) and D-3 (horizontal resolution $1 \mathrm{~km}$ ) are giving quite better result than D-1 (horizontal resolution $9 \mathrm{~km}$ ) and D-2 and D-3 are giving almost same value. So the indices value of D-3 is giving here.

\subsubsection{Graphical Analysis of Indices}

To demonstrate the difference indices value (1 hourly) over D-3, graphical figure has been drawn. Along with these, area average rainfall value (hourly) is also represented here. Area average rainfall value is used to give relation with this indices value to form TS. From figure 9. It is seen that all indices increase sharply before few hours of recorded storm time (Case-1 and Case-2).

Case-1: 12:50 UTC, 17 ${ }^{\text {th }}$ May, 2019

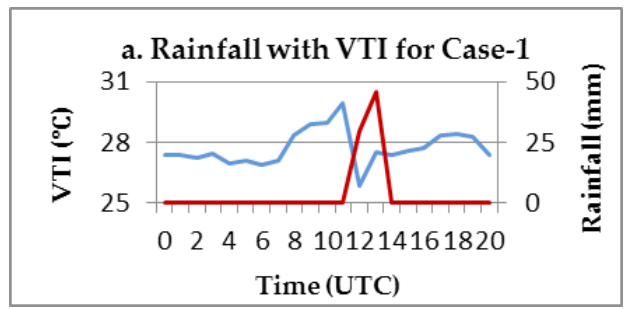

Case-2: 12:22 UTC, 31 ${ }^{\text {st }}$ March, 2019

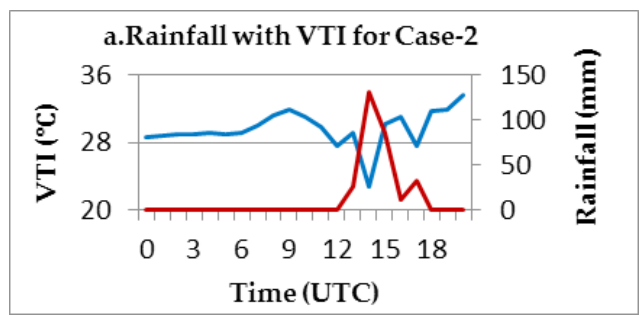



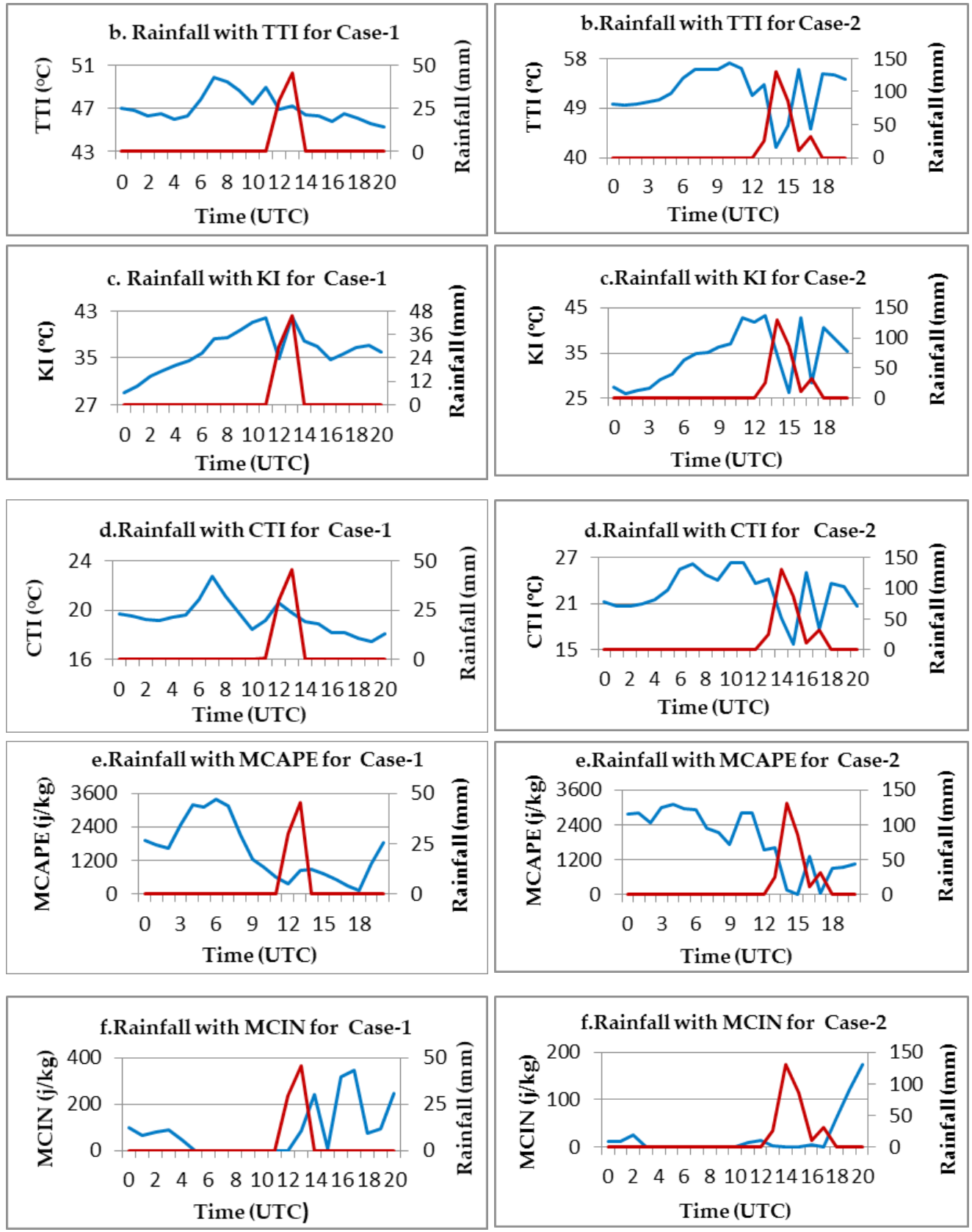

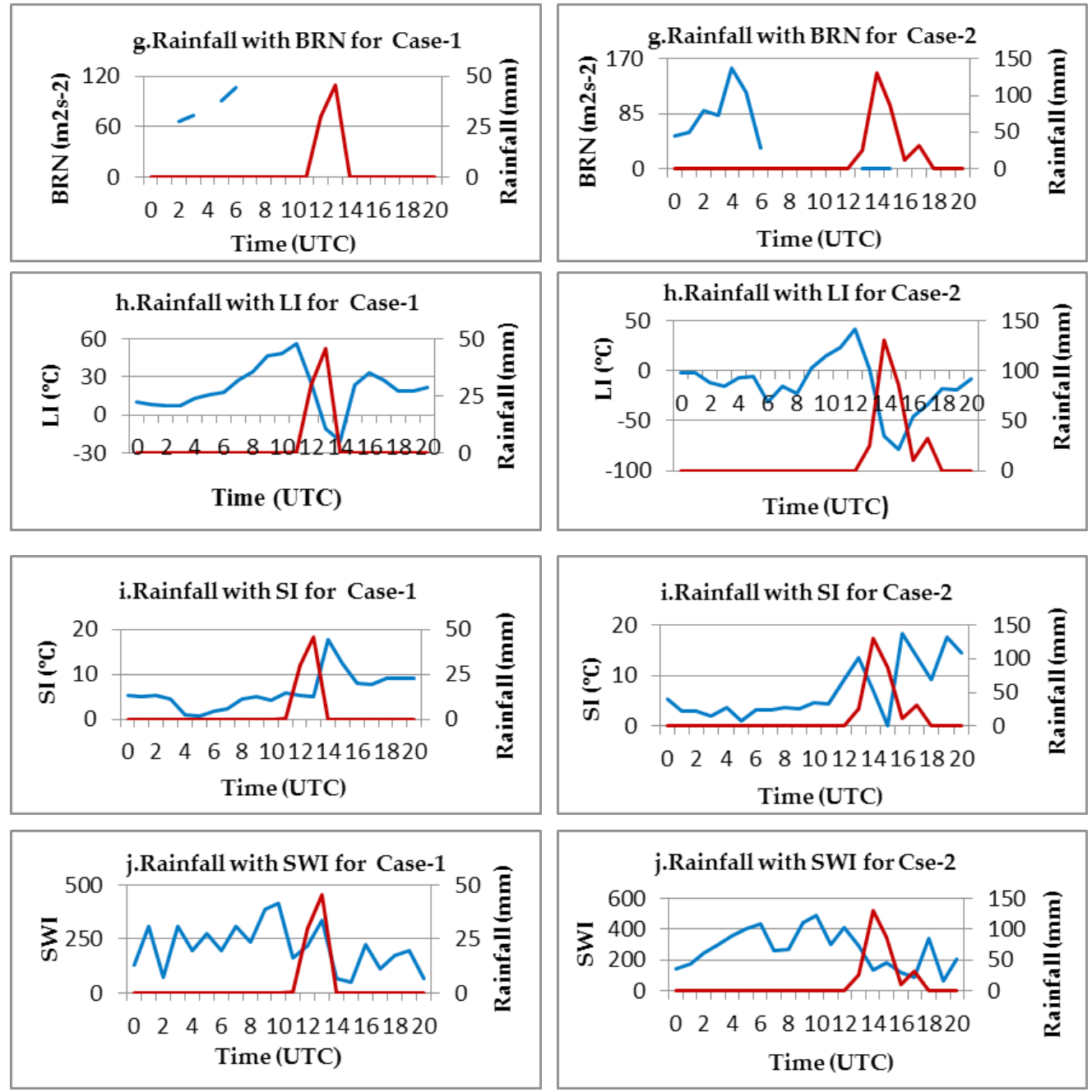

Figure 9. Hourly value of indices (a. VTI, b. TTI, c. KI, d. CTI, e. MCAPE, f. MCIN, g. BRN, h. LI, i. SI, j. SWI) for (I) Case-1 from 00 UTC to 20 UTC of $17^{\text {th }}$ May, 2019 and (II) Case-2 from 00 UTC to 20 UTC of $31^{\text {st }}$ March, 2019.

From figure (9) it is seen that all indices increase sharply before few hours of recorded of storm time (Case-1 and Case-2. The synthesized results of indices (Table 2) are given below:- 
Table 2. Synthesized Results of Indices

\begin{tabular}{|c|c|c|c|}
\hline Parameters & $\begin{array}{l}\text { Case-1(12:50 } \\
\text { UTC; 17th May, } \\
\text { 2019) }\end{array}$ & $\begin{array}{l}\text { Case-2(12:22 UTC; } \\
\text { 31st March, 2019) }\end{array}$ & $\begin{array}{l}\text { Remark (Hour of highest } \\
\text { value before storm) }\end{array}$ \\
\hline $\begin{array}{l}\text { Highest VTI } \\
\text { and Time }\end{array}$ & $\begin{array}{l}29.924^{\circ} \mathrm{C}, 11 \\
\mathrm{UTC}\end{array}$ & $31.89^{\circ} \mathrm{C}, 9$ UTC & $\begin{array}{l}\text { Case- } 1: 1 \text { h } 50 \text { mins; Case- } 2: 3 \\
\text { h } 22 \text { mins }\end{array}$ \\
\hline $\begin{array}{l}\text { Highest TTI } \\
\text { and Time }\end{array}$ & $49.83^{\circ} \mathrm{C}, 7$ UTC & $57.42^{\circ} \mathrm{C}, 10 \mathrm{UTC}$ & $\begin{array}{l}\text { C-1: } 5 \text { h } 50 \text { mins; C-2: } 2 \text { h } 22 \\
\text { mins }\end{array}$ \\
\hline $\begin{array}{l}\text { Highest KI } \\
\text { and Time }\end{array}$ & $41.68^{\circ} \mathrm{C}, 11 \mathrm{UTC}$ & $42.62^{\circ} \mathrm{C}, 11 \mathrm{UTC}$ & $\begin{array}{l}\text { C-1: } 1 \text { h } 50 \text { mins, C-2: } 1 \text { h } 22 \\
\text { mins }\end{array}$ \\
\hline $\begin{array}{l}\text { Highest CTI } \\
\text { and Time }\end{array}$ & $22.74^{\circ} \mathrm{C}$ & $26.43^{\circ} \mathrm{C}, 10 \mathrm{UTC}$ & $\begin{array}{l}\text { C-1: } 5 \text { h } 50 \text { mins; C-2: } 2 \text { h } 22 \\
\text { mins }\end{array}$ \\
\hline $\begin{array}{l}\text { H. MCAPE \& } \\
\text { Time }\end{array}$ & $\begin{array}{l}3345.95 \mathrm{j} / \mathrm{kg}, 6 \\
\text { UTC }\end{array}$ & $3090.68 \mathrm{j} / \mathrm{kg}, 4$ UTC & $\begin{array}{l}\text { C-1: } 6 \text { h } 50 \text { mins, C-2: } 8 \text { h } 22 \\
\text { mins }\end{array}$ \\
\hline $\begin{array}{l}\text { Lowest MCIN } \\
\text { \& Time }\end{array}$ & $0.1 \mathrm{j} / \mathrm{kg}, 5-11 \mathrm{UTC}$ & $0.1 \mathrm{j} / \mathrm{kg}, 3-10$ UTC & C-1: $7 \mathrm{~h}, \mathrm{C}-2: 9 \mathrm{~h}$ \\
\hline $\begin{array}{l}\text { Highest BRN } \\
\text { \& Time }\end{array}$ & $\begin{array}{l}105.98 \mathrm{~m} 2 \mathrm{~s}-2,6 \\
\text { UTC }\end{array}$ & 147 m2s-2, 5 UTC & $\begin{array}{l}\text { C-1:6h } 50 \text { mins, C-2: } 7 \text { h } 22 \\
\text { mins }\end{array}$ \\
\hline $\begin{array}{l}\text { Lowest LI \& } \\
\text { Time }\end{array}$ & $7.32^{\circ} \mathrm{C}, 2 \mathrm{UTC}$ & $-34.43^{\circ} \mathrm{C}, 6 \mathrm{UTC}$ & $\begin{array}{l}\text { C-1:10 h } 50 \text { mins; C-2:6 h } 22 \\
\text { mins }\end{array}$ \\
\hline $\begin{array}{l}\text { Lowest SI \& } \\
\text { Time }\end{array}$ & $0.76^{\circ} \mathrm{C}, 5 \mathrm{UTC}$ & $1.03^{\circ} \mathrm{C}, 5 \mathrm{UTC}$ & $\begin{array}{l}\text { C-1:7 h } 50 \text { mins; C-2:7 h } 22 \\
\text { mins }\end{array}$ \\
\hline $\begin{array}{l}\text { Highest SWI } \\
\text { \& Time }\end{array}$ & $366.204,12$ UTC & $496.12,9$ UTC & $\begin{array}{l}\text { C-1: } 50 \text { mins; C-2: } 3 \text { h } 22 \\
\text { mins }\end{array}$ \\
\hline \begin{tabular}{|l|} 
Highest \\
dissipating \& \\
Time
\end{tabular} & $\begin{array}{l}45.6021 \mathrm{~mm}, \\
\text { 13UTC }\end{array}$ & $\begin{array}{l}130.252 \mathrm{~mm}, 14 \\
\text { UTC }\end{array}$ & $\begin{array}{l}10 \text { mins after storm; } 1.5 \mathrm{~h} \\
\text { after storm }\end{array}$ \\
\hline
\end{tabular}

\subsection{Error Statistics}

To calculate error RMSE (Root Mean Square Error) has been used in this study. RMSE of model value has been calculated with observed data of Bangladesh Meteorological Department (BMD). Upper air data is used here as observed data. But only data of 00 UTC is available for the selected cases, not 1200 UTC. Moreover, data of Wyoming University are not available for these selected cases. CAPE and CIN value are not available in some time of event dates. So, MCAPE and MCIN value have been calculated instead of CAPE and CIN for indices. On the contrary, observed value of MCAPE and MCIN are not available. But observed value of CAPE and CIN is available at 00 UTC for all selected cases. So CAPE and CIN indices have been used here to calculate the rate of RMSE with other eight indices (Table 3). 
Table 3. Rate of Error Statistics

\begin{tabular}{|c|c|c|}
\hline Parameters & $\begin{array}{c}\text { Case-1(12:50 UTC; } \mathbf{1 7}^{\text {th }} \\
\text { May, 2019) }\end{array}$ & $\begin{array}{c}\text { Case-2(12:22 UTC; } \mathbf{3 1}^{\text {st }} \\
\text { March, 2019) }^{\text {2t }}\end{array}$ \\
\hline VTI & $0.37 \%$ & $0.83 \%$ \\
\hline TTI & $0.59 \%$ & $1.76 \%$ \\
\hline KI & $1.83 \%$ & $5.05 \%$ \\
\hline CTI & $2.02 \%$ & $3.1 \%$ \\
\hline CAPE & $6.32 \%$ & $17.43 \%$ \\
\hline CIN & $28.69 \%$ & $9.93 \%$ \\
\hline BRN & $10 \%$ & $14.27 \%$ \\
\hline LI & $10 \%$ & $3.23 \%$ \\
\hline SI & $24.05 \%$ & $48.6 \%$ \\
\hline SWI & $6.48 \%$ & $2.91 \%$ \\
\hline
\end{tabular}

\section{Discussion}

Atmospheric instability is a critical factor in determining thunderstorm whether it will occur or not. The main goal of this study is to investigate the importance of instability indices in forming thunderstorm as well as forecasting of thunderstorm. This study estimates of 10 instability indices (VTI, TTI, KI, CTI, MCAPE, MCIN, BRN, LI, SI, SWEAT) of atmospheric which are widely used in the world to practice for the thunderstorm prediction. The values of indices were computed using the output data of the WRF-ARW mesoscale model. WRF version 4.0.3 has been used in this study. The model has been runned for 72 hours (one day before to one day after of storm) with 9 , 3, 1 (three way nested domains) $\mathrm{km}$ spatial resolution including 32 vertical levels. $0.25^{\circ}$ $\mathrm{X} 0.25^{\circ}$ six hourly global data assimilation system (GDAS) data were used as initial and lateral boundary conditions. The schemes which give better result (based on journal) for TS have used here. Certain parameters, including mean sea level pressure, temperature, wind at different levels $(925 \mathrm{hPa}$ and $300 \mathrm{hPa}$ ), and relative humidity (vertical cross section) are simulated to understand the atmospheric conditions of selected cases. For both case model shows low pressure area for case location. In case of Temperature, model shows that both case are giving $26^{\circ} \mathrm{C}$ temperature. In case of wind there is seen high speed of wind for every case. From cross section of relative humidity it is told that to form TS there is needed of $80 \%$ of moisture availability.

The instability indices have been calculated for both case to see either it maintains threshold limit or not before storm which is important for forming of TS and other mesoscale system. Area average hourly rainfall has been also calculated with indices to understand the nature of cases. When rainfall rate is high for any date or case, there may be some events. In this study it is seen that Rainfall is highest on the recorded time of storm, but indices values are highest before few hours ago of storm. It happens for most of the indices. For which cases rainfall rate is as high, TS is as stronger for that case. It is seen clearly for both cases.

Stability indices reveal that the atmosphere may be stable in the morning (about 10-12 hours before the occurrence). For case-1, BRN value is not available always. 
Besides, SI and LI did not reach threshold limit for both case. In case of VTI, TTI, KI and CTI indices both case maintain threshold limit. For VTI, both case are giving highest value before $3 \mathrm{~h}$ of storm and this value started to increase $6 / 7 \mathrm{~h}$ before of storm. For TTI, both cases are giving highest value before $6 \mathrm{~h}$ of storm and started to increase $7 \mathrm{~h}$ and 3 $\mathrm{h}$ before of storm respectively. For KI, this value started to increase from starting of the event date and reach in highest position $3 \mathrm{~h}$ before of storm for both case. Same thing is seen for CTI indices where highest value are $6 \mathrm{~h}$ and $3 \mathrm{~h}$ before of storm and value started to increase $7 \mathrm{~h}$ before of storm. For SWEAT indices, highest value is $3 \mathrm{~h}$ before of storm for both case. MCAPE gives better result among all of these indices and it reaches on its highest position before $5 / 6$ h of events. Besides, for MCIN, it is giving the lowest value $(0.1 \mathrm{j} / \mathrm{kg})$ from starting of the day on event days. From this study we can say, highest (maintaining threshold limit) indices value is needed in forming of TS. When it is seen that indices values are increasing sharply, thunderstorm can be happened on that particular location rapidly.

In this study root mean square error has been also calculated to see the difference of model derived value and observed value (Bangladesh Meteorological Department). There is seen clearly that case- 1 is simulated better than case- 2 except CTI and SWI indices. Case- 1 is giving $0.37 \%$ for VTI, $0.59 \%$ for TTI, $1.83 \%$ for KI, $2.02 \%$ for CTI, $6.32 \%$ for CAPE, $28.69 \%$ for CIN, $10 \%$ BRN, $10 \%$ for LI, $24.05 \%$ for SI and $6.48 \%$ error for SWI.

This study has some limitations. They are- short interval data are needed. But upper air data is used here which is recorded only at 00 UTC and 12 UTC. Between these only 00 UTC data of Bangladesh Meteorological Department are available in the events date. Furthermore, data of Wyoming University are not available in these selected dates. Therefore, Observational data of MCAPE and MCIN are not available. That's why CAPE and CIN value have been used to calculate RMSE.

\section{Conclusions}

On the basis of the present study, the following conclusion can be made:

The study shows that the presence of a low pressure area over western part of Bangladesh and adjoining area of Best Bengal and intruding towards the country is a common condition in both cases along with high temperature $\left(>26{ }^{\circ} \mathrm{C}\right)$ as well as availability of high moisture (about $80 \%$ ).

The value of instability indices increases sharply before 5/6 hours of thunderstorm occurrence, but indices value reaches highest about 3 hours before of storm for both the cases. Highest value (maintaining threshold limit) of indices requires forming the storms. When the indices values are increasing sharply, storms are forming on that particular location rapidly.

The simulated rainfall shows highest on the time of occurrence of storms, but indices values are highest before 3 hours of storm. It happens for most of the indices. Rainfall shows good correction with the strength of the storm for the both cases, the higher amount of rainfall the stronger the storm and vice versa.

The study shows that the RMSE is very less for case- 1 than case- 2 except CTI and SWI indices. Case- 1 is giving $0.37 \%$ for VTI, $0.59 \%$ for TTI, $1.83 \%$ for KI, $2.02 \%$ for CTI, $6.32 \%$ for CAPE, $28.69 \%$ for CIN, $10 \%$ BRN, $10 \%$ for LI, $24.05 \%$ for SI and $6.48 \%$ error for SWI. 
In future, more works have to be done conducting more number of thunderstorm cases with the different combination of physics and dynamics as well as domain size and resolution for the better understanding of thunderstorms over study area.

Acknowledgments: First author would like to thank Department of Meteorology, University of Dhaka, Bangladesh and Department of Atmospheric Science, Central University of Rajasthan, India for giving the opportunity to carry out this research, their guidance, patience, motivation, enthusiasm and immense knowledge to complete this work. Thanks are due to Bangladesh Meteorological Department for providing meteorological data and information for this research work.

Conflicts of Interest: The authors declare no conflict of interest for this article.

\section{References}

Ahasan, M.N., Islam, M.N. and Ferdousi, N., 2008, August. A diagnostic study on synoptic and environmental conditions associated with Nor'westers in and around Bangladesh using MM5 model. In Proceedings of the SAARC Seminar on Nor'westers and Tornadoes over the SAARC Region and their Forecasting E Preparedness (pp. 20-21).

Ahasan, M.N., Quadir, D.A., Khan, K.A. and Haque, M.S., 2014. Simulation of a thunderstorm event over Bangladesh using wrf-arw model. Journal of Mechanical Engineering, 44(2), pp.124-131.

Brooks, H.E., Lee, J.W. and Craven, J.P., 2003. The spatial distribution of severe thunderstorm and tornado environments from global reanalysis data. Atmospheric Research, 67, pp.73-94.

Chaudhari, H.S., Sawaisarje, G.K., Ranalkar, M.R. and Sen, P.N., 2010. Thunderstorms over a tropical Indian station, Minicoy: Role of vertical wind shear. Journal of Earth System Science, 119(5), pp.603-615.

Chowdhury, M.H.K. and Karmakar, S., 1986, January. Pre-monsoon nor'westers in Bangladesh with case studies. In Proceedings of the SAARC Seminar on Local Severe Storms (pp. 147-166).

Davis, C., Atkins, N., Bartels, D., Bosart, L., Coniglio, M., Bryan, G., Cotton, W., Dowell, D., Jewett, B., Johns, R. and Jorgensen, D., 2004. The Bow Echo and MCV Experiment: Observations and Opportunities: Observations and Opportunities. Bulletin of the American Meteorological Society, 85(8), pp.1075-1094.

Das, R.C., Munim, A.A., Begum, Q.N. and Karmaker, S., 1994. A diagnostic study on some local severe storms over Bangladesh. JOURNAL-BANGLADESH ACADEMY OF SCIENCES, 18, pp.81-81.

Das, S., 2009. Composite characteristics of nor'westers observed by TRMM and simulated by WRF model. SAARC Meteorolog. Research Centre (SMRC).

Gubenko, I.M. and Rubinshtein, K.G., 2015. Analysis of the results of thunderstorm forecasting based on atmospheric instability indices using the WRF-ARW numerical model data. Russian Meteorology and Hydrology, 40(1), pp.16-24.

Johns, R. H., \& Doswell III, C. A. (1992). Severe local storms forecasting. Weather and Forecasting, $7(4), 588-612$.

Karmakar, S., 2001. Climatology of thunderstorm days over Bangladesh during the pre-monsoon season. Bangladesh J Sci Technol, 3(1), pp.103-112.

Rajeevan, M., Kesarkar, A., Thampi, S.B., Rao, T.N., Radhakrishna, B. and Rajasekhar, M., 2010, February. Sensitivity of WRF cloud microphysics to simulations of a severe thunderstorm event over Southeast India. In Annales Geophysicae (Vol. 28, No. 2, pp. 603619). Copernicus GmbH. 
SAARC-STORM, 2013, “SAARC STORM Pilot Field Experiment 2011, SAARC Meteorological Research Centre (SMRC)", SMRC Scientific Report, 46, 51 pp

Tajbakhsh, S., Ghafarian, P. and Sahraian, F., 2012. Instability indices and forecasting thunderstorms: the case of 30 April 2009. Natural Hazards \& Earth System Sciences, 12(2).

Thompson, C., \& Lin, Y., 1985. Pre-storm stability conditions of the meso-scale thunderstorm environment during AVE. SESAME-V (20-21 May 1979), 14th Conference on Severe Local storms. Indianapolis, Indiana, 29, 131-134.

Tyagi, A., Sikka, D.R., Goyal, S. and Bhowmick, M., 2012. A satellite based study of pre-monsoon thunderstorms (Nor'westers) over eastern India and their organization into mesoscale convective complexes. Mausam, 63(1), pp.29-54.

Vujović, D., Paskota, M., Todorović, N. and Vučković, V., 2015. Evaluation of the stability indices for the thunderstorm forecasting in the region of Belgrade, Serbia. Atmospheric Research, 161, pp.143-152.

Webster, P.J., Bradley, E.F., Fairall, C.W., Godfrey, J.S., Hacker, P., Houze Jr, R.A., Lukas, R., Serra, Y., Hummon, J.M., Lawrence, T.D.M. and Russell, C.A., 2002. The JASMINE pilot study. Bulletin of the American Meteorological Society, 83(11), pp.1603-1630.

Yamane, Y. and Hayashi, T., 2006. Evaluation of environmental conditions for the formation of severe local storms across the Indian subcontinent. Geophysical research letters, 33(17).

Yamane, Y., Hayashi, T., Dewan, A.M. and Akter, F., 2010. Severe local convective storms in Bangladesh: Part I. Climatology. Atmospheric Research, 95(4), pp.400-406.

Zheng, Y., K. Alapaty, J.A. Herwehe, A.D. Del Genio, and D. Niyogi, 2016: Improving high resolution weather forecasts using the Weather Research and Forecasting (WRF) Model with an updated Kain-Fritsch scheme. Mon. Wea. Rev., 144, 833-860.

Zipser, E.J., Cecil, D.J., Liu, C., Nesbitt, S.W. and Yorty, D.P., 2006. Where are the most intense thunderstorms on Earth? Bulletin of the American Meteorological Society, 87(8), pp.10571072. 
